\title{
Research on Corporate Governance of Multinational Enterprises
}

\author{
Yao $\mathrm{Yu}$ \\ Guizhou university of finance and economics \\ Guiyang city, Guizhou province, China
}

\author{
Liu Liangcan \\ Guizhou university of finance and economics \\ Guiyang city, Guizhou province, China
}

\begin{abstract}
With the advent of the era of globalization, the pursuit of competitive advantages across national boundaries and the realization of profit maximization has increasingly become the starting point of enterprise management strategy. Therefore, transnational corporations play a decisive role in the national economy. As a result, it is the most urgent thing to study the governance of multinational corporations in order to ensure their prosperity. This paper uses the theory of corporate governance to analyze the particularity and limitation of the governance of transnational corporations so as to improve the governance of transnational corporations.
\end{abstract}

Keywords-multinational corporation; Corporate governance; Multinational corporate governance

\section{The CONNOTATION OF MUltinational CORPORATION}

\section{A. Definition of multinational corporation}

In the competition of comprehensive national strength of countries in the world, multinational enterprises can be said to be the vanguard of the international market. The number, scale and competitive strength of a country with multinational companies will greatly influence or even determine the comprehensive strength of the country [1-3]. At the same time, the rise of transnational corporations has brought about the expansion of capital, broken the traditional international economic relations, and realized the globalization of production and market in a real sense.

In 1974, the United Nations adopted the name "transnational corporation" by a resolution of the council. The code of conduct on transnational corporations states: "a transnational corporation is a public, private or mixed-ownership enterprise entity formed between two or more countries, irrespective of its legal form and field of activity [4-7]; The enterprise operates under a decision-making system and realizes the coordinated policies and common strategies within the enterprise through one or more decision-making centers. The various entities in the enterprise are bound together by ownership or otherwise so that one or more of them can exercise effective influence over the activities of other entities, in particular by sharing knowledge, resources and responsibilities with other entities."

\section{B. The nature and characteristics of multinational corporation}

Transnational corporation is the product of contemporary capital expansion and the organizational form of production activities under highly developed productive forces. With the constant expansion of foreign investment in capitalist countries transnational corporations, as the carrier of international capital movement, provide an effective way for capitalists to grab higher profits [8-12]. In the accumulation of capital, multinational companies develop and grow continuously, thus creating a real international monopoly. As a result, transnational corporations have become an extremely important and independent part of the world economy that cannot be ignored. This phenomenon is unprecedented.

With the development of economic globalization, transnational corporations, as carriers of international capital flow, haveshown the following distinctive characteristics in the new global competition environment.

First, multinational corporations implement global strategic objectives and highly centralized unified management.

Second, multinational companies began to move closer to localization. As multinational companies face markets all over the world, they are inevitably affected by geographical dispersion and cultural diversity. When multinational companies are engaged in production and business activities in host countries, they are often confronted with cultural backgrounds quite different from their own. Different regional cultures will bring about differences in values and consumption patterns.

Third, overseas m\&a has become the main form of investment by multinational companies. Under the background of economic globalization, enterprises have entered the white-hot market competition, and the market share and enterprise scale determine the comprehensive competitiveness of enterprises.

\section{CORPORATE GOVERNANCE THEORY}

The thought and theoretical origin of corporate governance can be traced back to the 18th century, but until the first world war, corporate governance has not attracted the attention of scholars or the public. Britain did not make adjustments to corporate law until the 19th century. In Germany in the 1850s, the traditional corporate governance structure was overturned 
for the first time. It was not until the 1920s that listed companies began to play an important role in the economy of developed countries in Europe and America that people paid attention to it.

\section{A. Principal-agent theory}

Principal-agent theory is the corporate governance theory under information economics. Jensen and Meckling(1976) define principal-agent relationship as "a contractual relationship. Under such contracts, the principal employs an agent to perform certain tasks on their behalf, including delegating certain decision-making rights to the agent". According to the principal-agent theory, when the ownership and control rights of an enterprise are separated, there will be a conflict of interest between the principal and the agent of the enterprise, that is, the principal pursues the maximization of his own interests, while the agent pursues the least effort and the richest return.

\section{B. Shareholders' interests are paramount}

The theory of shareholders' interests above all else is the theory of putting shareholders' interests in the first place. Shareholders are the investors of the company, and the goal of the company's operation is to maximize shareholders' interests. Only by exercising the governance right in accordance with shareholders' interests can managers ensure the effectiveness of corporate governance.

\section{Stakeholder theory}

With the rapid development of the capital market, the increasingly changeable forms of enterprises, especially the highlighting of the importance of human capital, the stakeholder theory has entered the field of people's research [12-17]. According to stakeholder theory, individuals and groups that can affect the realization of organizational goals or are affected by the process of the realization of organizational goals can be regarded as stakeholders. The goal of stakeholder theory is to integrate companies most effectively and maximize corporate profits.

\section{THE PARTICULARITY OF CORPORATE GOVERNANCE OF MULTINATIONAL ENTERPRISES}

Due to its characteristics of operating business in many countries with the parent company as the core, multinational enterprises are different from other independent commercial companies, so they have many particularity in governance issues.

\section{A. The particularity of parent-subsidiary company governance}

Because of its multi-level and multi-legal characteristics, the parent company of a multinational enterprise is different from the governance objectives of a single enterprise. Its governance goal is not limited to efficiency optimization and cost minimization, focused more on management target of extensionality, namely to establish a stable cooperation between parent-subsidiary relationship, should not only give play to the role of the parent company's control and guide, and to reflect the independence of the subsidiary, implementation throughout the enterprise decision-making more scientific and efficiency optimization. Second, the traditional single enterprise is dominated by the vertical governance path, while the multi-dimensional governance path of multinational companies is characterized by the complex structure and the common collaborative governance between parent and subsidiary companies. Third, the interests between the parent and subsidiary companies need to be coordinated, but all of them must be subject to the maximization of the overall interests. Under such a premise, the board of directors of the subsidiary company seems to be responsible for the subsidiary company, but in fact it is responsible for the whole parent-subsidiary company.

\section{B. The control and restraint mechanism of the parent company}

The parent company has absolute control over the subsidiaries, but there are conflicts of interests between them. As an independent part, the subsidiary company needs to exercise certain independent options. Proper settlement of this issue will help the parent company and the subsidiary company play the best role.

How to balance the relationship between parent company and subsidiary company depends on the control relationship between parent company and subsidiary company. First, indirect control. In other words, the parent company holds the majority of the board of directors of the subsidiary company and exercises the control. Second, direct control. The parent company's overall control over its subsidiaries. Third, hybrid. Between the above two types, flexible measures should be taken according to the actual situation of the host country and subsidiaries.

\section{Governance structures go beyond national}

For domestic companies, their governance system is based on the provisions of the domestic company law, while foreign corporate governance mainly has the Anglo-American model and the German model. However, transnational corporations have transcended the borders of a country at the geographical level, so the governance structure has transcended the national nature. But as an economic entity, multinational companies need to control. At present, the lack of international legal framework applicable to the governance of transnational corporations, and the domestic regulatory mechanism for transnational corporations is not rigorous, leading to a stagnation of the governance of transnational corporations.

\section{LIMITATIONS OF CORPORATE GOVERNANCE IN MULTINATIONAL CORPORATIONS}

\section{A. The external environment}

\section{1) Economic market environment}

In the process of mne governance, the economic market condition of host country is the most important basic factor among all kinds of environmental factors faced by enterprises. In governance, multinational enterprises must study the economic conditions and trends of relevant countries in order to define the market size and development prospects. According to the economic development level of the host country, it can be divided into the following four categories: 1 . 2. Raw material export economy. 3. Industrial development economy. 4. Industrial economy. According to different levels 
of economic development, different governance models should be formulated for the governance of transnational corporations, which is indeed a big challenge. GDP and distribution should also be taken into account. GDP only reflects a country's overall economic strength, and the distribution pattern of social wealth can better reflect a country's economic performance and prospects. Full understanding of the host country's economic status and development trends is the premise and basis for effective governance of multinational enterprises.

\section{2) Sociocultural environment}

Social and cultural environment affects the governance and future expansion of multinational enterprises. Different countries have their own unique cultural environment, and operating in different countries requires enterprises to adapt to different cultures. First of all, cultural difference is the most important and crucial influencing factor in transnational corporate governance, which is mainly reflected in the cultural difference between host country and home country, as well as the difference between main culture and subculture of multinational companies. The culture of a particular region cultivates a group of people's unique way of thinking, cognition and behavior rules. Naturally, when people with different cultural brands enter multinational companies, their values and ways of thinking will to a large extent influence the formulation of policies and implementation of tasks of multinational companies, and correspondingly bring challenges in terms of governance. Secondly, due to its special status, education level is not only the carrier of historical and cultural inheritance, but also the way of cultural exchanges among countries. From the micro level, it determines personal career and corporate governance mode. If the target country's education level is low, the parent company will bear more governance pressure and cannot rely too much on local talents.

\section{B. The internal environment}

\section{1) The board of directors}

The reasonable size of the board of directors should be determined on the basis of weighing governance costs and governance benefits. The small size of the board of directors has many advantages, such as low variable cost, small chance of free-riding among directors and fast communication among members. However, it also has obvious shortcomings, such as insufficient knowledge reserve when solving complex problems of the company, low risk control ability of the board of directors and easy decision-making mistakes. With the expansion of the size of the board of directors, common wisdom has established the company's governance on the basis of scientific governance mechanism and achieved better governance results. However, as the communication among directors becomes more difficult, the free-riding behavior among directors increases, the CEO gains power advantage and other challenges, the efficiency of the board will decrease. The board of directors should be a balanced senior management team composed of different knowledge background, work experience, industry background and different interest groups.

\section{2) Independent director system}

The frequent occurrence of scandals in modern companies requires special attention to the strengthening of the supervision function of the board of directors. Improving the independence of the board of directors is the key to play the supervision function, and increasing the proportion of independent directors is crucial. The independent director is between the shareholders and the management, which does not affect his independent judgment and does not work for the company. However, there are some defects in the independent director system. There is no supervision subject. Once the independent director resigns or does nothing to damage the company's performance due to violation of regulations, there is no corresponding punishment system. On the other hand, lack of independent director assessment system basis and assessment institutions. Secondly, the level of professionalism is low. Multinational companies tend to pursue the celebrity effect of independent directors too much and ignore their business knowledge and management background, which makes it difficult for them to make valuable professional judgment on the company's decisions and other decisions. On the contrary, it will bring obstacles to the company's personnel governance. Finally, the independent director and the internal director bear the same legal responsibility to the company. The asymmetry of information makes it difficult for independent directors to make correct business judgments, so they take a conservative attitude towards risks.

\section{3) The board of supervisors}

The essence of corporate governance is to safeguard the interests of stakeholders. Modern companies must set up boards of supervisors to separate executive functions from supervisory functions to prevent members from colluding to the detriment of the company. However, due to the large number of departments and complex interpersonal relationships of multinational companies, the supervisory board is difficult to implement the supervisory function in place. In the enterprise everyone regards everything as the most precious as the code of conduct, resulting in the enthusiasm of the members of the board of supervisors is not high, and the supervisors do not actively exercise the legal supervision right to position in the important position of corporate governance, that "supervision" and "not supervision" is irrelevant. As time passes, the negligence of the board of supervisors will inevitably affect the effect of corporate governance. The board of supervisors should be independent of the board of directors, to ensure that the work is not affected and controlled by the board of directors, guarantee the objectivity of supervision and evaluation. However, at present, it is difficult to realize this in multinational companies. The board of directors has too much power, and the board of supervisors will turn a blind eye when they find problems, deal with problems in a superficial way, and consider the interests. It is difficult to enforce the law impartially, which makes the daily supervision become a mere formality. 


\section{CORPORATE GOVERnANCE EVALUATION}

After the emergence of modern corporate system in the middle and late 19th century, corporate owners put forward corporate governance evaluation in order to strengthen ownership control. The separation of ownership and management rights in modern companies and the resulting principal-agent relationship is the fundamental reason for the emergence of corporate governance evaluation. Due to asymmetric information and free-riding psychology, corporate shareholders need to understand the implementation status of agents through a series of review mechanisms and judge their achievements in governance behavior, governance performance and other aspects, so corporate evaluation becomes the objective demand of investors. Regulatory authorities also need to understand the situation of their regulatory objects through corporate governance evaluation.

\section{CONCLUSION}

Based on the theory of corporate governance, this paper studies the corporate governance performance of multinational enterprises. First of all, it analyzes the particularity of multinational corporations different from general corporate governance, including more hierarchical relations and agency relations. Secondly, it analyzes the internal and external factors that affect the governance of transnational corporations. Finally, the performance system of governance is analyzed from the perspective of governance evaluation. In short, due to its huge size and particularity of structure, multinational companies still have a lot of room to improve and improve governance, which is a long way to go.

\section{REFERENCE}

[1] Zhang yunling. On the formation and nature of transnational corporations $[\mathrm{J}]$. Study and thinking (journal of graduate school of Chinese academy of social sciences),1981(03):31-34+17.

[2] Wen xianwu. Reflections on the definition of transnational corporation [J]. Journal of wuhan university (social science edition),1987(04):25-28.

[3] Geng liping. The nature of transnational corporations and the utilization of foreign capital in China [J]. Economics dynamics, 1997(11):26-29.

[4] Cao tingqiu. Three challenges facing corporate governance theory [J]. Journal of shanxi university of finance and economics,2003(05):47-51.

[5] Wang xiaohong. Definition of transnational corporations should be open [J]. China economic and trade guide,2003(15):26+25.

[6] Wei xu. On the particularity of governance of multinational companies $[\mathrm{J}]$. Science and technology information development and economy,2006(22):206-207.

[7] Shen hongtao, shen yifeng. Modern evolution of corporate governance theory -- from shareholder benefit maximization to stakeholder theory [J]. Economic journal,2008(06):108-111.

[8] Liu jinshi, wang GUI. Corporate governance theory: exploration, evaluation and comparison of similarities and differences $[\mathrm{J}]$. Dynamics of economics,2011(05):80-85.

[9] Wang yong. Comparison of governance structure of transnational corporations [J]. Science and technology \& enterprise,2011(11):51.

[10] Fang gang, cui shengchao, zhou jian. Transformation of transnational business governance model and path selection $[\mathrm{J}]$. Corporate governance review,2011,3(01):33-40.

[11] Wang yong. Particularity of governance of multinational companies [N]. Study times,2012-10-08(004).

[12] Wang yong. On transnational corporations and new concepts of governance [J]. Journal of CPC central party school,2012,16(05):92-95.

[13] Wang bin. Research on global governance model of multinational companies [J]. Journal of social science,2013(01):132-136.

[14] Li han. Corporate governance issues in overseas m\&a of multinational companies [J]. Economist,2013(05):66-68

[15] Jia Lin. Characteristics of governance structure of multinational corporations [J]. Enterprise economics,2014,33(11):25-28.

[16] Zhou changbao, Lin runhui, li kanghong, xie zongxiao. New progress in research on the governance of overseas subsidiaries of transnational corporations $[\mathrm{J}]$. Foreign economy and management,2016,38(05):99-112.

[17] Suo bang. On the new characteristics of transnational corporations under economic globalization [J]. Knowledge economy,2016(17):49-51. 